\title{
Husbandry practices associated with the presentation of abnormal behaviours in Chilean Creole horses
}

\author{
Prácticas de manejo asociadas a la presentación de conductas anormales \\ en caballos Criollo chileno

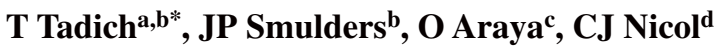 \\ a'Becario CONICYT, Programa Doctorado en Ciencias Veterinarias, Facultad de Ciencias Veterinarias, \\ Universidad Austral de Chile, Valdivia, Chile. \\ bInstituto de Ciencia Animal, Facultad de Ciencias Veterinarias, Universidad Austral de Chile, Valdivia, Chile. \\ 'Instituto de Ciencias Clínicas, Facultad de Ciencias Veterinarias, Universidad Austral de Chile, Valdivia, Chile. \\ ${ }^{\mathrm{d}}$ Centre for Behavioural Biology, University of Bristol, Langford House, Langford, Bristol, UK.
}

\begin{abstract}
RESUMEN
Las conductas anormales generalmente se desarrollan en ambientes subóptimos para el equino y tienden a reducir su bienestar. El objetivo de este estudio fue determinar la prevalencia de conductas anormales en equinos Criollo chileno, asociando su presentación a características del animal y de su manejo. Se encuestaron 23 criaderos contemplando información del animal y de manejo. Se obtuvo información de 441 equinos, 116 fueron menores de un año, grupo que no presentó conductas anormales. De los 325 equinos adultos un $11 \%$ presentó conductas anormales de las cuales $3,1 \%$ corresponde a estereotipias y $8 \%$ a otras conductas anormales, siendo la lignofagia la más frecuente en este último grupo. Se encontró una asociación significativa entre la presentación de conductas anormales y la categoría semental, mientras que la función también se asoció de forma significativa con la presentación de conductas anormales, siendo la realización de dos funciones (reproducción y deporte) de mayor riesgo. En relación al manejo se encontró una asociación significativa entre la entrega de menos de $60 \%$ de forraje en la ración y la presentación de conductas anormales. Un $41 \%$ permanece más de 6 horas estabulado; $37 \%$ no tiene contacto conespecífico entre establos; y sólo el $21 \%$ ocupa cama de paja. Estas prácticas no se asociaron significativamente a la presentación de conductas anormales. El establecer factores de riesgo para la presentación de conductas anormales permitirá implementar prácticas de manejo adecuadas en los sistemas de producción del caballo Criollo chileno, y con ello mejorar el bienestar de esta raza.
\end{abstract}

Key words: abnormal behaviour, Chilean Creole horse, stereotypic behaviour, husbandry.

Palabras clave: conducta anormal, caballo criollo chileno, estereotipia, manejo.

\section{INTRODUCTION}

Stereotypies are repetitive, relatively invariant behaviour patterns with no apparent function (Mason 1991). The development of these behaviours is generally associated with horses being managed in suboptimal environments either currently or in the past (Hothersall and Casey 2012). Some husbandry practices that have been considered as risk factors for the development of these behaviours include confinement, isolation from other horses, feeding practices, bedding material, and weaning method, among others (Broom and Kennedy 1993, McGreevy et al 1995a, Nicol 1999, Waters et al 2002, Christie et al 2006, Clegg et al 2008, Visser et al 2008, Wickens and Heleski 2010). The role of biological characteristics such as breed, sex and sire has also been studied (Vecchiotti and Galanti 1986, Luescher et al 1998, Bachman et al 2003, Albright et al 2009). High performance horses are usually managed

Accepted: 10.05.2012.

* Casilla 567 Valdivia, Chile; tamaratadich@gmail.com intensively in stables and are therefore subjected to many of the risk factors mentioned above, with little time available for socialization and other highly motivated behaviours for equines, such as grazing (Tadich y Araya 2010). This is the case, for example, for Thoroughbreds that have a higher risk of developing these abnormal behaviours (Bachman et al 2003, Albright et al 2009).

Most studies on the prevalence of abnormal behaviours in horses and the possible risk factors involved come from the application of survey research methodology (Wickens and Heleski 2010), with the exception of few longitudinal studies (Waters et al 2002) and epidemiological studies (Albright et al 2009). These studies have reported stereotypy prevalences between $3.8-9.4 \%$ for crib-biting/ windsucking, $2.6-8.3 \%$ for weaving and $1.2-5.5 \%$ for box-walking in the UK (McGreevy et al 1995a, McBride and Long 2001). Recently in the USA Albright et al (2009) reported a prevalence of $4.5 \%$ for crib-biting among different breeds. The longitudinal study by Waters et al (2002) on the other hand, reported a prevalence of $34.67 \%$ for abnormal behaviours, with stereotypies accounting for $17.4 \%$ of the population under study. 
Across the country the most popular breed of horses is the Chilean Creole Horse, this horse is used for the Chilean rodeo, a national sport, and breeding centres can be found along the country. There is not much information published about the management practices used during breeding and training of these horses and how they could be affecting their welfare. Muñoz et al (2009) published a study on the prevalence of stereotyped behaviour in Chilean Creole Horses, they selected one hundred horses that met the requirements of being over 2 years of age, already trained to accept a rider and that were kept in stables all day or part of it. They reported a prevalence of $10 \%$ of horses presenting stereotypies, box walking being the most common one with 8 horses presenting the behaviour. The authors only looked for associations between age and sex and the presentation of these behaviours, reporting a significant association between stallions and box walking (Muñoz et al 2009). This is why the aim of the present study was to establish association between the presentation of abnormal behaviours and some of the husbandry practices currently used for Chilean Creole horses in order to set a baseline for future studies and to be able to provide recommendations to owners on better management practices taking into account the welfare of their horses.

\section{MATERIAL AND METHODS}

A survey was applied to 23 Chilean Creole horse breeding centres through the 4 veterinarians in charge of them. Veterinarians completed the questionnaires according to the information obtained during their regular visits to each centre (Vet 1: 8 centres, Vet 2: 6 centres, Vet 3: 5 centres, Vet 4: 4 centres). The survey included questions on husbandry practices such as feeding schedule, amount of roughage and concentrate given, stabling hours, social contact between horses, bedding material and weaning system. Information about the horse including sex, age and function of the animal was also included. All surveys had an ethogram attached with the definitions and pictures of the most common stereotypies (crib-biting, box walking and weaving) and other abnormal behaviours such as wood chewing (McDonnell 2003, table 1), in order to facilitate their understanding of the behaviours.

Application of the survey through veterinarians allowed us to obtain information on 441 equines from 23 different Chilean Creole horse breeding centres. These were distributed along 4 regions of Chile (El Maule, Los Ríos, Los Lagos and Aysén).

For the presentation of results and the discussion, abnormal behaviours were categorized in two groups, one group included those classified as stereotypes (crib-biting, weaving and box walking); and a second group with other abnormal behaviours such as wood chewing.

Data was tabulated and analysed through descriptive statistics and Chi-square test in order to establish possible associations between the presentation of abnormal behaviours and husbandry practices and between abnormal behaviours and animal factors. The Chi-square test was only applied on the data from the 325 adult horses through contingency tables of 2 by 2, no cells had less than 6 numbers. All data was analysed with SAS ${ }^{\circledR} 9.1$ statistics software and a significance level of $\mathrm{P}<0.05$ was established.

\section{RESULTS AND DISCUSSION}

From the 441 horses assessed, 116 were individuals of less than 1 year of age. Since weaning systems, especially abrupt box weaning techniques, have been implicated as a risk factor for the development of stereotypic behaviour (Waters et al 2002) the weaning technique used was assessed. Abrupt box group weaning was used by $47.8 \%$ out of the 23 breeding centres, followed by $26.1 \%$ using individual gradual weaning, $17.4 \%$ abrupt box individual weaning. Only one centre used gradual group weaning in which one mare is removed from at a time from the paddock. Although most Chilean Creole foals were abruptly box weaned, none of the foals or yearlings in this study was reported to present abnormal behaviours (figure 1). Chilean Creole foals are usually weaned between 6 and 8 month of age, and after the weaning process is finished they are kept in paddocks. The post weaning housing system was a management factor strongly associated to the presentation of abnormal behaviours (Waters et al 2002). Intake of high energy feeds was also considered as a possible cause by Waters et al (2002). The fact that most Chilean Creole yearlings are kept in groups at paddocks could mean that these horses were at lower risk of presenting abnormal behaviours; on the other hand because they receive less intensive human handling these behaviours could pass undetected by the owners and veterinarians resulting in an underestimation of their presentation. This is not the case for adult horses kept in paddocks, since these are exercised and handled on a daily basis. Feeding practices of foals should be studied in more detail in order to establish if Chilean Creole foals are managed differently than foals of other breeds, as the ones considered in the study of Waters et al (2002).

From the 23 breeding centres surveyed 14 (61\%) were reported by their veterinarians to had at least 1 horse showing an abnormal behaviour, all veterinarians reported more than 1 of the centres under their care presenting horses with stereotypic behaviour. Since no foals or yearlings were reported to present abnormal behaviours only the remaining 325 adult horses were included in the association tests. From the group of adult horses $11.1 \%$ presented overall abnormal behaviours, from which $3.1 \%$ were stereotypies and $8 \%$ other abnormal behaviours being wood chewing the most common one ( 26 horses) in this last group. The most common stereotypy was group crib-biting ( 8 horses), whereas weaving and box walking were only reported to be performed by one horse each. These results differ greatly from those reported by Muñoz et al (2009), who 


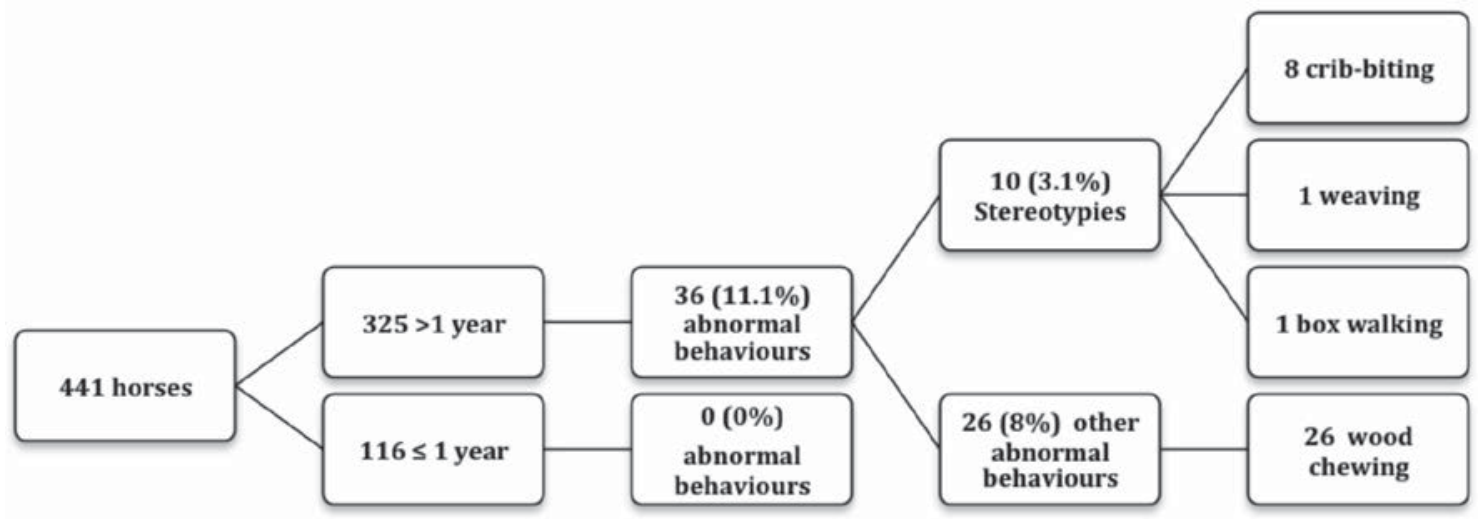

Figure 1. Distribution of the total occurrences and percentages of abnormal behaviours registered according to their classifications and age of horses.

Distribución del total de ocurrencias y porcentaje de conductas anormales registradas de acuerdo a su clasificación y edad de los equinos.

reported a $10 \%$ prevalence of stereotypies, a number much higher than the $3.1 \%$ of stereotypies found in the present study. Crib-biting was the most common stereotypy, this is in accordance to other studies where crib-biting has also been the most prevalent stereotypy (McGreevy et al $1995^{\mathrm{a}}$, McBride and Long 2001, Waters et al 2002), but does not agree with the results from Muñoz et al (2002) for Chilean Creole horses where they reported box walking as the most common stereotypy (8 out of 100 horses) followed by only 2 horses that showed crib-biting. The prevalence of wood-chewing (8\%) reported in this study, although lower than the $30.3 \%$ reported by Waters et al (2002) should be further studied to investigate a possible connection with crib-biting and with some management factors such us roughage availability in the diet. In this study, the provision of hay (only roughage provided) to horses varied from $2 \mathrm{~kg}$ to $12 \mathrm{~kg}$ per day, for those horses kept in boxes.

In relation to sex (figure 2), 52\% of the adult horses were mares, $24.3 \%$ geldings and $23.7 \%$ stallions. Abnormal behaviours were significantly associated with stallions ( $\mathrm{P}<0.0001$, table 1). Muñoz et al (2009) also found a significant association between Chilean Creole stallions and box walking in their study, and Luescher et al (1998) also reported a higher prevalence for geldings and stallions. Stallions are usually housed in individual enclosures to prevent accidental breeding and aggression (Wickens and Heleski 2010). This isolation could increase the risk of developing abnormal behaviours. Chilean Creole stallions are usually housed individually, but are turned out together with other horses. In this study the function of the horse was also associated with the development of abnormal behaviours ( $P=0.005$, figure 3$)$, with those horses used for breeding and for competition being at higher risk, this is the case of most Chilean Creole stallions. This could indicate that a more intensive management could be more important than the sex itself.

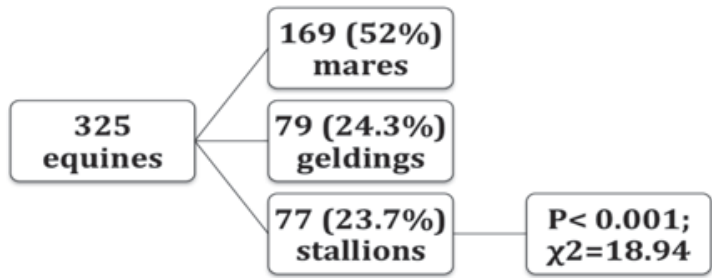

Figure 2. Distribution of equines according to sex (total numbers and percentages). The $\mathrm{P}$ value for the Chi Square test indicates the significant association between stallions and overall presentation of abnormal behaviours.

Distribución de los equinos de acuerdo al sexo (números totales y porcentajes). El valor de P para la prueba de Chi cuadrado indica la asociación significativa entre los machos enteros y la presentación de conductas anormales.

In relation to feeding practices, the horses received between 2 and 3 rations daily, composed on an average of over $50 \%$ forage of the total volume (maximun $83.3 \%$ forage), and $4.9 \%$ of the horses being managed exclusively on prairie (none of these horses presented abnormal behaviours). A significant association was found between receiving less than $60 \%$ of forage and the presentation of abnormal behaviours $(\mathrm{P}=0.03)$ (figure 4$)$. This association between low levels of forage and high levels of concentrate in the diet of horses has also been reported by other studies as a risk for the development of stereotypic behaviour (McGreevy et al 1995 a, Waters et al 2002).

The housing of Chilean Creole horses in individual boxes is a common practice, especially for those used in rodeo competition. Forty one percent of the horses spend more than 6 hours per day inside the box, $37 \%$ do not have either visual or tactil contact with conspecifics while in the stable, and only in $21 \%$ of the boxes have straw bedding, since wood shavings are used for the remaining ones 
Table 1. Ethogram of the abnormal behaviours observed (stereotyped and other abnormal behaviours) observed. Modified from McDonnell (2003).

Etograma de las conductas anormales (estereotipadas y otras conductas anormales) observadas. Modificado de McDonnell (2003).

\begin{tabular}{l|ll}
\hline \multicolumn{2}{c}{ Behaviour } & \multicolumn{1}{c}{ Description } \\
\hline & Crib-biting / windsucking & $\begin{array}{l}\text { The horse may or not support the upper front teeth against any solid material. It tenses } \\
\text { the muscles of the neck, forcing air into the cranial portion of the oesophagus, making a } \\
\text { characteristic noise. The horse can lick the object before and after the fixing. } \\
\text { The animal moves the head from side to side. This rhythmic movement can involve neck, } \\
\text { forelimbs and even hindlimbs. Most times it is performed standing with the head out of the } \\
\text { stable, but it can also be done standing in the middle of it. }\end{array}$ \\
The horse wanders in circles inside the box, walking, trotting or galloping. If there is more \\
space, it can make more complex circuits.
\end{tabular}

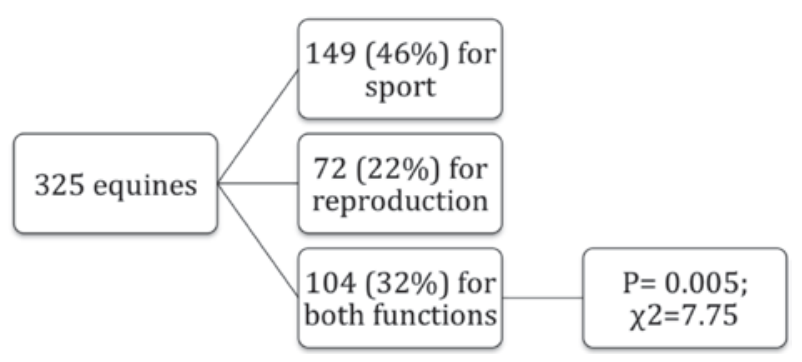

Figure 3. Distribution of equines according to their function (total numbers and percentages). The $\mathrm{P}$ value for the Chi Square test indicates a significant association between performing both functions and the presentation of overall abnormal behaviours.

Distribución de los equinos de acuerdo a su función (número total y porcentajes). El valor de P para la prueba de Chi cuadrado indica asociación significativa entre la realización de ambas funciones (deporte y reproducción) y la presentación de conductas anormales.

(figure 4). None of these housing practices was significantly associated with the presentation of abnormal behaviours, although they have all been positively associated with the development of abnormal behaviours by other authors (McGreevy et al $1995^{a}$, McGreevy et al $1995^{b}$, Waters et al 2002, Bachman et al 2003). One factor that could have had an effect over our results is the small amount of time that these horses spent inside their boxes, compared with the case of thoroughbreds that spend most of the day inside the box. McGreevy et al $\left(1995^{\mathrm{a}}\right)$ found that the risk of presentation of stereotypic behaviour increased significantly when spending less than 4 hours outside the stall, and that endurance horses spend significantly more time out of their stalls than dressage and eventing horses For animals stabled permanently or with restricted turnout, the environment limits their behavioural options considerably (Hothersall and Casey 2012) increasing the risk of developing abnormal behaviours.

Straw may ameliorate some of the behavioural problems associated with restricted fibre diets, as horses occupy themselves more with straw rather than other bedding types (Werhahn et al 2010). Goncalves et al (2002) warn that impaction colic often appears just after change to straw bedding, particularly if there is no other source of fibre available, although Tinker et al (1997) were not able to establish an association between colic and any type of bedding.

Many owners attempt to physically prevent horses from performing abnormal behaviours (McBride and Long 2001). Owners of $81.1 \%$ of the horses that performed an abnormal behaviour used physical methods to prevent performance of the behaviour, including the use of electric fences to avoid crib-biting and wood-chewing. According to McBride and Cuddeford (2001) impeding the performance of abnormal behaviours through physical restriction resulted in an increase in cortisol levels. The main problem with the use of these methods is that they do not address the primary cause of the behaviour and that they may further reduce the welfare of the horse.

This study identified possible relationships between management factors such as amount of roughage in the diet and factors related to the animal such as sex and function and the presentation of abnormal behaviours in Chilean Creole horses. Further research on genetic and behavioural aspects of this breed would be useful to further understand the development of these behaviours. The implementation of longitudinal studies, although time costly, is required to completely understand the management factors involved in the development of abnormal behaviours in horses, feeding practices before and after weaning is a possible starting point of interest to investigate in more detail. 


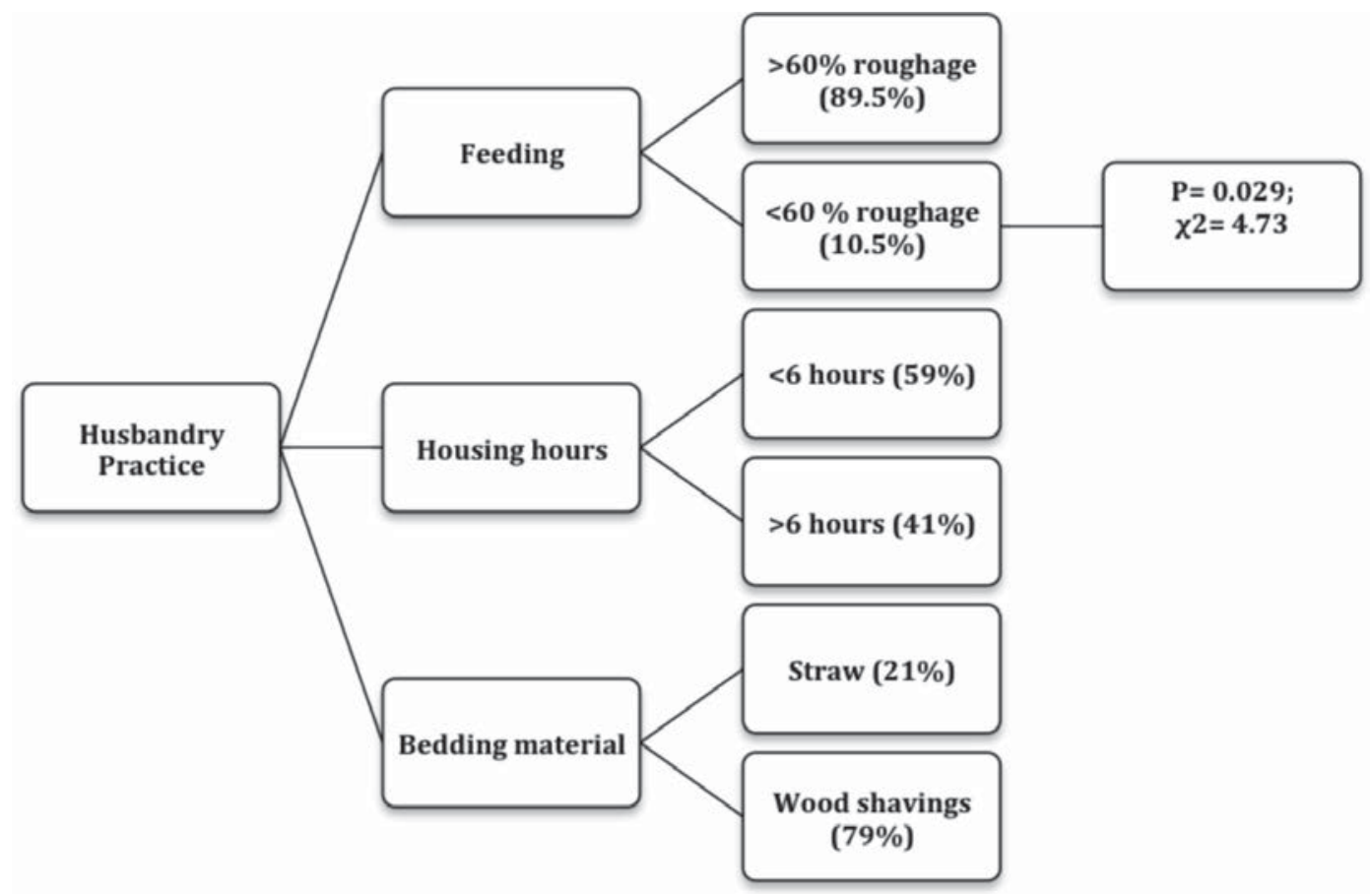

Figure 4. Husbandry practices included in the survey and their percentage distribution. The $\mathrm{P}$ value for the Chi Square test indicates the significant association found between providing less than $50 \%$ roughage in the diet and the presentation of overall abnormal behaviours.

Prácticas de manejo incluidas en la encuesta y su distribución porcentual. El valor de P para la prueba de Chi cuadrado indica una asociación significativa entre la entrega de menos de $50 \%$ de forraje en la ración y la presentación de conductas anormales.

\section{SUMMARY}

Abnormal behaviours usually develop in environments that are suboptimal for the horses and tend to reduce their welfare. The aim of this study was to determine the prevalence of abnormal behaviours in Chilean Creole horses, and associate their presentation with characteristics of the animal and their management. Twenty-three breeding centres were surveyed face to face through their veterinarians. Information on 441 horses was obtained, of which 116 were foals or yearlings that did not present any abnormal behaviours. Of the remaining 325 adult horses $11.1 \%$ presented abnormal behaviours; $3.1 \%$ corresponded to stereotypes and $8 \%$ to wood-chewing. A significant association was found between sex (stallions) and the presentation of abnormal behaviours, while function was also significantly associated, with combination of sport and reproductive activities presenting a higher risk. In relation to husbandry practices horses received feeding 2 or 3 times daily. Diets comprised on average $50 \%$ roughage from the total feed ration (roughage + oats). A significant association was found between providing less than $60 \%$ of forage in the diet and the presentation of abnormal behaviours. Forty one percent of horses were kept in stables for over 6 hours per day, $37 \%$ had no type of contact with conspecifics while in the stable and $21 \%$ had straw bedding. None of these practices were associated with the presentation of abnormal behaviours. Establishing factors related to the development of abnormal behaviours in horses can allow improvement of their welfare through the implementation of appropriate husbandry practices in the equine production systems of the Chilean Creole horse.

\section{ACKNOWLEDGEMENTS}

We appreciate the help provided by the veterinarians: Rodrigo Briones, César Márquez, Javier Tapia and Rodrigo Muñoz in the data collection process.

\section{REFERENCES}

Albright JD, HO Mohammed, CR Heleski, CL Wickens, KA Houpt. 2009. Crib-biting in US horses: Breed predispositions and owner perceptions of aetiology. Equine Vet $J 41,455-458$.

Bachman I, L Audigé, M Stauffacher. 2003. Risk factors associated with behavioural disorders of crib-biting, weaving and box-walking in Swiss horses. Equine Vet J 35, 158-163.

Broom DM, MJ Kennedy. 1993. Stereotypies in horses: their relation to welfare and causation. Equine Vet Educ 5, 151-154.

Christie JL, CJ Hewson, CB Riley, MA McNiven, IR Dohoo, LA Bate. 2006. Management factors affecting stereotypies and body condition score in non-racing horses in Prince Edward Island. Can Vet $J 47,136-143$.

Clegg HA, P Buckley, MA Friend, PD McGreevy. 2008. The ethological and physiological characteristics of cribbing and weaving horses. Appl Anim Behav Sci 109, 68-76.

Goncalves S, V Julliand, A Leblond. 2002. Risk factors associated with colic in horses. Vet Res 33, 641-652.

Hothersall B, R Casey. 2012.Undesired behaviour in horses: A review of their development, prevention, management and association with welfare. Equine Vet Educ 24, 485-497.

Luescher UA, McKeown DB, Dean H 1998. A cross-sectional study on compulsive behaviour (stable vices) in horses. Equine Vet $J$, Suppl 27, 14-18.

Mason G. 1991. Stereotypies: a critical review. Anim Behav 41, 1015-1037. McBride SD, D Cuddeford. 2001. The putative welfare reducing effect of preventing equine stereotypic behaviour. Anim Welfare 10, 173-189.

McBride SD, L Long. 2001. The perception and subsequent management of equine stereotypic behaviour by horse owners: implications for animal welfare. Vet Rec 148, 799-802. 
McDonnell S. 2003. A practical field guide to horse behaviour, the equid ethogram. Eclipse Press, Hong Kong, China.

McGreevy PD, PJ Cripps, NP French, LE Green, CJ Nicol. 1995 ${ }^{\text {. }}$ Management factors associated with stereotypic and redirected behaviour in the Thoroughbred horse. Equine Vet $J$ 27, 86-91.

McGreevy PD, NP French, CJ Nicol. 1995 ${ }^{\mathrm{b}}$. The prevalence of abnormal behaviours in dressage, eventing and endurance horses in relation to stabling. Vet Rec 137, 36-37.

Muñoz L, J Torres, O Sepúlveda, C Rehhof, R Ortiz. 2009. Frecuencia de comportamientos anormales estereotipados en caballos chilenos estabulados. Arch Med Vet 41, 73-76.

Nicol CJ. 1999. Understanding equine stereotypies. Equine Vet J, Suppl 28, 20-25.

Tadich T, O Araya. 2010. Conductas no deseadas en equinos. Arch Med Vet 42, 29-41.

Tinker MK, NA White, P Lessard, CD Thatcher, KD Pelzer, B Davis, DK Carmel. 1997. Prospective study of equine colic risk factors. Equine Vet J 29, 454-458.
Vecchiotti GG, R Galanti. 1986. Evidence of heredity of cribbing, weaving and stall walking in thoroughbred horses. Livest Prod Sci 14, 91-95.

Visser EK, AD Ellis, CG Van Reenen. 2008. The effect of two different housing conditions on the welfare of young horses stabled for the first time. Appl Anim Behav Sci 114, 521-533.

Waters AJ, CJ Nicol, NP French. 2002. Factors influencing the development of stereotypic and redirected behaviours in young horses: findings of a four years prospective epidemiological study. Equine Vet J 34, 572-579.

Werhahn H, E Hessel, I Bachhausen, HFA Van den Weghe. 2010. Effects of different bedding material on the behavior of horses housed in single stalls. J Equine Vet Sci 30, 425-431.

Wickens C, CR Heleski. 2010. Crib-biting behavior in horses: A review. Appl Anim Behav Sci 128, 1-9. 